\title{
Władza świadectwa. Między polityką a etyką
}

Grzegorz Niziołek

TEKSTY DRUGIE 2018, NR 3, S. 241-252

DOI: $10.18318 /$ td.2018.3.16

$\mathbf{K}^{\mathrm{t}}$

to tworzy świadectwo? Mówiący czy słuchający? Jaka relacja ich łączy? Czy jest jakoś regulowana? Co lub kto legitymizuje świadectwo? A co je deprecjonuje? Te pytania stawiano wielokrotnie. Badania nad świadectwem, a nawet sama instytucja świadectwa zrodziły się na skrzyżowaniu wielu dyskursów. Towarzyszyła mu też refleksja psychoanalityczna, która takie kategorie jak "prawda" i „fałsz" poddawała gruntownej rewizji, odnajdując fałsz w prawdzie i na odwrót. Etyczne podejście do świadectw polega bowiem na uznaniu pracy afektu, który może zniekształcać fakty. Tego rodzaju podejście wymagało stworzenia instancji, która ma władzę nad świadectwem, nawet jeśli stara się ją ukryć. Która wie, jak go słuchać, jak je zapisywać, jak je czytać, jak je archiwizować. Można nawet zaryzykować twierdzenie, że ukrycie władzy nad świadectwem jest podstawowym warunkiem jej zdobycia. Nawet jeśli analizujący twierdzi, że on również podlega władzy analizowanego, że mu służy, należy zachować krytyczną możliwość wątpienia w równowagę tych wzajemnych relacji władzy. W ten
Grzegorz Niziołek prof. dr hab., pracuje na Wydziale Polonistyki UJ. Redaktor naczelny czasopisma "Didaskalia". Autor Polskiego teatru Zagłady (2013) oraz monografii o twórczości Tadeusza Różewicza, Krystiana Lupy i Krzysztofa Warlikowskiego. 
sposób świadectwo zostaje wyposażone we władzę, którą często ktoś inny sprawuje w jego imieniu. Oczywiście mowa tutaj o świadectwie doświadczenia traumatycznego, którego wypowiedzenie nigdy nie jest rzeczą łatwą, które napotyka na opór w sferze publicznej i równocześnie ma duży potencjał polityczny, ponieważ dotyczy doświadczeń wypieranych i tabuizowanych.

Ten mechanizm wyposażania świadectwa we władzę został najlepiej opisany poprzez psychoanalityczny mechanizm fetyszyzacji. Warto w tym kontekście wspomnieć o polemice Dominicka LaCapry z Carolyn Steedman'. Steedman starała się podważyć - z perspektywy metodologii historycznych - dekonstrukcyjną krytykę władzy archiwum przeprowadzoną przez Jacques'a Derridę. Odrzuciła jego tezę, jakoby historyk był uwikłany w „metafizyczne poszukiwanie początków"2, starała się dowieść, że skupia się on w swojej pracy na „bardziej codziennej, pokornej, a często brudnej działalności"3. LaCapra precyzyjnie wskazuje na te punkty wywodu Steedman, które ustanawiają władzę historyka nad archiwum (bo tylko historyk jej zdaniem umie czytać teksty znajdujące się w archiwum i konstruować na ich podstawie wiedzę o przeszłości). Wywody Steedman przeczą więc założeniom jej artykułu, stwierdza LaCapra.

Najciekawsza w kontekście moich rozważań jest jednak jego konkluzja dotycząca polityki tożsamości i „metafizyki” doświadczenia:

posiadanie pewnego doświadczenia jako - powiedzmy - Afroamerykanin czy niemiecki Żyd może nadawać autorytet epistemologiczny założeniom dotyczącym tego doświadczenia. Ale takie domniemane doświadczenie nie jest absolutne, nie wykracza także poza zasięg doświadczenia danej osoby na tyle, by uprawomocniać wypowiedzi dotyczące faktów, sądów i argumentacji. I musiałoby ono być legitymizowane w odniesieniu do rzeczywiście stawianych żądań - żądań, które podlegają dyskusji i debacie. ${ }^{4}$

1 LaCapra polemizuje z artykułem Steedman Something She Called a Fever: Michelet, Derrida, and Dust opublikowanym na łamach "American Historical Review" (2001 No. 106, s. 1159-80) w swojej książce Historia w okresie przejściowym. Doświadczenie, tożsamość, teoria krytyczna (przeł. K. Bojarska, Universitas, Kraków 2009, s. 37-50).

3 Tamże.

4 Tamże, s. 46. 
Zaskakująca to konkluzja, biorąc pod uwagę, że dotychczasowy wywód LaCapry odnosił się wyłącznie do kwestii związanych z historiografią i archiwum. Nie ulega jednak wątpliwości, że również zwolennicy polityki tożsamości mają prawo żywić podobny uraz wobec aktów dekonstrukcji. LaCapra w cytowanym fragmencie z wielką przenikliwością dostrzegł złożone relacje między polityką tożsamości a sferą publiczną, między doświadczeniem a politycznym żądaniem, między politycznym żądaniem a jego legitymizacją.

Świadectwa traumy coraz silniej rządzą mechanizmami sfery publicznej, przekształcając jej koncepcję, poszerzając jej granice o doświadczenia często wcześniej wykluczane z jej obszaru. Nie chodzi jednak wyłącznie o zwiększoną inkluzywność sfery publicznej i związane z tym narastanie antagonizmów w jej ramach, lecz także o nowe kanały cyrkulacji i nowe instytucje zajmujące się pracą nad świadectwami traumy, a w konsekwencji - o strukturalną transformację. Zjawiska te wywołują bowiem potężne zakłócenia relacji władzy w sferze publicznej i przewartościowanie psychologicznych skutków tych relacji. Nancy Fraser, podejmując krytyczny namysł nad koncepcją sfery publicznej w ujęciu Jürgena Habermasa, zwracała uwagę na to, że współczesne ruchy feministyczne często pod określeniem „sfera publiczna” utożsamiają ze sobą trzy porządki: państwa, oficjalnej ekonomii związanej z rynkiem pracy i dyskursu publicznego 5 . W tak spłaszczonej perspektywie krytyka mizoginicznej kultury może prowadzić np. do postulatów wprowadzenia państwowej cenzury. Rozwijając argumentację Fraser, można powiedzieć, że każdemu zdarzeniu dyskursywnemu rozpoznanemu jako opresyjne przypisuje się w tak zdefiniowanej sferze publicznej znaczenie polityczne równe działaniom władzy państwowej, a w konsekwencji świadectwa traumy podlegają natychmiastowej reartykulacji w obszarze żądań politycznych. Co nie znaczy, że Fraser idealizuje Habermasowską ideę sfery publicznej. Dostrzegając konieczność jej redefinicji, próbuje jednak zachować jej autonomię wobec sfer ekonomii i państwa, nie zrównuje konfliktów dyskursywnych z przemocą polityczną, jak czynią to często radykalne i rewolucyjnie nastawione ruchy emancypacyjne.

Z innej perspektywy próbował uchwycić to zjawisko upolitycznienia świadectw traumy Slavoj Žižek w swojej krytyce postkolonializmu, odwołując się do modelu Freudowskiej melancholii, która nie chce zerwać z ciągłym odgrywaniem scen doznanej krzywdy, odrzuca pracę żałoby prowadzącą do

5 N. Fraser Rethinking the Public Sphere: A Contribution to the Critique of Actually Existing Democracy, "Social Text" 1990 No. 25/26. 
uwolnienia się od bolesnych doświadczeń. Etyczny aspekt melancholii (jako wierności wobec świadectw niesprawiedliwej przeszłości) zostaje przekuty na argument polityczny. Žižek stwierdza więc, że etyczna rehabilitacja melancholii w myśli postkolonialnej - wbrew intencjom samego Freuda - staje się formą ideologicznego cynizmu, ,pozwala nam twierdzić, że jesteśmy wierni swoim etnicznym korzeniom, a zarazem uczestniczyć w globalnej grze kapitalistycznej"6. Žižkowi nie chodzi o to, że zjawiska kolonialnej i neokolonialnej dyskryminacji już się nie zdarzają, lecz o to, w jaki sposób zostają wykorzystane w politycznej grze. I do jakiego stopnia instytucje (należy rozumieć to pojęcie jak najszerzej) zwalczające zjawiska dyskryminacji są autentycznie zainteresowane ich realnym przezwyciężeniem. Nawet jeśli uznać oskarżenie o cynizm za demagogiczny chwyt mogący osłabić polityczne znaczenie ruchów emancypacyjnych i antydyskryminacyjnych, należy jednak wziąć pod uwagę istnienie znaczącej niezbieżności między sferą artykulacji etycznych i politycznych, którą to niezbieżność ruchy te starają się często ukryć bądź zatrzeć. A nawet usiłują nie dopuścić do dyskusji na ten temat.

Warunkiem sprawowania władzy nad świadectwem stało się wypracowanie niezwykle elastycznych sposobów odczytywania go, kategoryzowania, umieszczania w rozmaitych ramach. W imię umocnienia rangi świadectwa starano się obalić władzę archiwum jako instytucji o uregulowanych zasadach selekcjonowania i porządkowania dokumentów tylko po to, by w to miejsce ustanowić ideę nadarchiwum, panarchiwum, archiwum o ruchomych granicach, archiwum zdecentralizowanego, archiwum performatywnego, archiwum afektywnego. W konsekwencji archiwum poszerzyło swoje granice. Niemal każde działanie w obszarze publicznym (artystyczne, polityczne, społeczne, naukowe) znalazło się teraz w obszarze archiwum i w polu toczonych tam walk o władzę. W konsekwencji wyobrażenie sobie czegoś „niepublicznego”, czyli nieprzynależącego do archiwum, przestało być możliwe. A idea weryfikowania i legitymizowania świadectw traumy została uznana za opresję, a wręcz powtórną wiktymizację. I nawet jeśli zasadą archiwum performatywnego jest postawa samokrytyczna, nakazująca ujawniać własną pozycję w polu władzy, nie zmienia to faktu, że świadectwo podlega czyjejś władzy, może być przez nią prowokowane, a następnie wykorzystywane. Można w związku z tym postawić pytanie, czy stworzenie archiwum gromadzącego ślady traumy, jej świadectwa stało się już nieodłączną zasadą każdego politycznego żądania przywrócenia sprawiedliwości. Wskazywałaby

6 S. Žižek Melancholia i akt etyczny, przeł. M. Szuster, „Res Publica Nowa” 2001 nr 10, s. 95. 
na to chociażby praktyka legitymizowania swoich praw przez każdą większość poprzez odwołanie się do krzywd doznanych ze strony mniejszości.

Najbardziej rozległa i pogłębiona wiedza na temat świadectwa i pozycji świadka powstała, rzecz jasna, w obszarze badań nad Zagładą. Tutaj dokonała się zarówno intronizacja, jak i detronizacja świadka. Punktami zapalnymi, które doprowadziły do przemyślenia wielu dogmatów na temat świadectwa, stała się, po pierwsze, sprawa Binjamina Wilkomirskiego, fałszywego świadka Zagłady, a po drugie - późna krytyka Shoah Claude’a Lanzmanna. Historia Wilkomirskiego obnażyła sprawnie działające instytucjonalne mechanizmy podtrzymujące autorytet świadków Zagłady i równocześnie wytwarzające nieustanne zapotrzebowanie na świadectwa. Dominick LaCapra pisał w związku z fałszerstwem Wilkomirskiego o zjawisku utowarowienia doświadczenia traumatycznego („wspomnienia” Wilkomirskiego reklamowano na okładce jako „książkę, której się nie czyta, lecz doświadcza”). A tego rodzaju fetyszyzacja doświadczenia pociąga za sobą zawieszenie „możliwości krytycznej analizy i oceny"7. Krytyka filmu Lanzmanna ujawniła z kolei ideologiczne założenia, które legitymizowały daleko posuniętą manipulację świadectwami, która dla pierwszych widzów Shoah pozostawała niewidzialna. Nałożenie na Shoah Lanzmanna filtrów krytyki feministycznej i postkolonialnej odsłoniło złożoną sferę dyskryminujących reżimów przenikających struktury narracyjne filmu. Oba te przypadki (Wilkomirskiego i Lanzmanna) łączy zdaniem LaCapry wspólne im obu pragnienie utożsamienia się z ofiarami. LaCapra analizuje to zjawisko poprzez psychonalityczne mechanizmy przeniesienia i, co więcej, zauważa polityczne jego konsekwencje w sferze publicznej. Trauma ma zdolność sakralizowania świadectw, co stanowi zagrożenie dla dyskursywności sfery publicznej, a w konsekwencji zamyka perspektywę przepracowania. Tego rodzaju doświadczenie, jak twierdzi LaCapra, wymyka się bowiem osądowi politycznemu.

Chciałbym w związku z tym, idąc za sugestiami LaCapry, zwrócić uwage na kwestię niejawnego oddziaływania dyskursu o świadectwach Zagłady na współczesne ruchy emancypacyjne i związaną z nimi politykę tożsamości.

7 D. LaCapra Historia w okresie przejściowym..., s. 65-66.

8 Por. m.in.: M. Hirsh, L. Spitzer Gendered Translations: Claude Lanzmann's "Shoah", w: Claude Lanzmann's "Shoah": Key Essays, ed. by S. Liebman, Oxford University Press, Oxford 2007, s. 175-190; M. Olin Lanzmann's Shoah and the Topography of the Holocaust Film, "Representations" Winter 1997 No. 57; D. Głowacka Współ-pamięć, pamięć "negatywna" i dylematy przekładu W"wycinkach"Shoah Claude'a Lanzmanna. "Teksty Drugie" 2016 nr 6; G. Niziołek Lęk przed afektem, „Didaskalia” $2016 \mathrm{nr} 131$. 
Moja wstępna teza mówi, że są to obszary niemal całkowicie rozłączne (głównie za sprawą dogmatu o wyjątkowości Zagłady), a równocześnie oddziałujące na siebie. Świadczy o tym późna krytyka filmu Lanzmanna, wskazująca na jego ukryte ideologiczne uwikłania, ale i ostrożność, z jaką Michael Rothberg formułuje swoją koncepcję pamięci wielokierunkowej' ${ }^{9}$ w ramach której bada oddziaływanie dyskursu holokaustowego na powojenne konflikty polityczne o genezie kolonialnej. Nie do końca przekonujące wydają się jego argumenty podważające stanowisko Waltera Benna Michaelsa stawiającego pytanie, dlaczego w kompleksie muzeów w Waszyngtonie znajduje się Muzeum Holokaustu, a nie ma tam muzeum dokumentującego zbrodnie Amerykanów wobec czarnoskórej ludności ${ }^{10}$. Rothberg łagodzi radykalność tak postawionego pytania, konstruując dwa modele pamięci i ustanawiając etyczną wyższość pamięci wielokierunkowej nad pamięcią konkurencyjną. Przenosi argumentację o charakterze politycznym w obręb dyskursu pamięciowego. Tworzy tym samym rodzaj sylogizmu, za pomocą którego zbywa pytanie o zasadę dostępu do tak symbolicznie oznakowanej przestrzeni publicznej, jaką jest waszyngtoński National Mall. Co więcej, zaciera rozróżnienie między sferą sądów moralnych i politycznych. Wywyższa zasadę pamięci wielokierunkowej, nie biorąc pod uwagę faktu, że także ona operuje licznymi wykluczeniami i że pewne roszczenia mogą, jak się okazuje, zostać wypowiedziane jedynie w trybie politycznej konfrontacji. Potencjalna debata o dużym znaczeniu politycznym, odsłaniająca relacje między polityką a sferą symboliczną, zostaje w konsekwencji uznana przez Rothberga za etycznie niewłaściwą. Co więcej, Rothberg bezkrytycznie przyjmuje założenie, że badania nad świadectwami Holokaustu wytworzyły paradygmat pozwalający badać każde inne doświadczenie ludobójstwa. Nie zastanawia się nad tym, jakiego rodzaju zniekształcenia tego rodzaju matryca wytwarza, gdy zostaje zastosowana do odmiennych sytuacji.Założenie wielokierunkowości pamięci kulturowej nie podważa w jego koncepcji centralnego usytuowania epistemologii związanej z badaniami nad Zagładą.

Dyskurs na temat świadectw Zagłady, choć był przecież zawsze dyskursem o konsekwencjach politycznych, akcentował przede wszystkim kwestie etyczne, a jego konkluzje miały charakter etyczny, a nie polityczny.

9 M. Rothberg Pamięć wielokierunkowa. Pamiętanie Zagłady w epoce dekolonizacji, przeł. K. Bojarska, Wydawnictwo Instytutu Badań Literackich PAN, Warszawa 2015.

10 W.B. Michaels Plots Against America: Neoliberalism and Antiracism, "American Literary History” 2006 Vol. 18, No. 2 (Summer), s. 289-300. 
Te rozstrzygnięcia o charakterze etycznym nadawały mu autorytet, ukrywały przesłanki polityczne, które jako uwikłane w relacje władzy nigdy takiego autorytetu nie mają. Zjawisko to nazwę polityczną performatyką traumy, która została przeniesiona na grunt współczesnych ruchów emancypacyjnych poszukujących skutecznych narzędzi legitymizacji swoich żądań.

Zjawisko to uchwyciła, jako jedna z pierwszych, Judith Butler"1. Nic dziwnego, że właśnie ona. Sama Butler mówiła wprost, jakie znaczenie dla ukształtowania się jej postawy politycznej miało zarówno jej żydowskie pochodzenie, jak i zaangażowanie w ruchy emancypacyjne. Butler dokonała znaczącego przesunięcia w odniesieniu do performatyki traumy, akcentując jej polityczność i równocześnie dystansując się wobec dyskursu etycznego. Przywołując poglądy Emanuela Levinasa, które tworzą filozoficzne uzasadnienie dla etyki świadectwa i traumy, zaatakowała go za jego publiczną wypowiedź, że Palestyńczycy „nie mają Twarzy” w tym wzniosłym, etycznym i traumatycznym wymiarze, jaki zakłada jego koncepcja ${ }^{12}$. I nie tyle chodziło jej o zdyskredytowanie jego filozofii, ile o umieszczenie jej skutków także w sferze publicznej i politycznej. Nic dziwnego zatem, że Butler tyle uwagi poświęciła postaci Antygony, która formułuje swoje zakazane pragnienie w obszarze politycznym, w sferze polis ${ }^{13}$. Butler doskonale rozumie mowę traumatycznego świadectwa, ale równocześnie sprawdza jego znaczenia w polu konfliktów politycznych, jest nieufna wobec absolutyzowania racji etycznych, które domagają się uznania całkowicie poza porządkiem racji politycznych - rozważa polityczne konsekwencje każdego takiego żądania wypowiedzianego w sferze publicznej.

Lauren Berlant poddała wnikliwej krytycznej analizie politykę traumy, która zdominowała współczesne myślenie o sprawiedliwości społecznej ${ }^{14}$. Stawiane przez nią pytania dotyczą m.in. jakości wiedzy, jaką straumatyzowany podmiot może zdobyć o relacjach społecznych. Berlant nie podważa

11 J. Butler Ethical Ambivalence, w: Ethical Turn, ed. by M.B. Garber, B. Hanssen, R.L. Walkovitz, Routledge, London 2000, s. 15-28.

12 J. Butler Na rozdrożu. Żydowskość i krytyka syjonizmu, przeł. M. Filipczuk, Wydawnictwo Krytyki Politycznej, Warszawa 2014, s. 68-87.

13 J. Butler Żq̨danie Antygony. Rodzina między życiem a śmierciq̨, przeł. M. Borowski, M. Sugiera, Księgarnia Akademicka, Kraków 2010.

14 L. Berlant The Subject of True Feeling: Pain, Privacy, and Politics, w: Cultural Pluralism, Identity Politics, and the Law, ed. by A. Sarat, T.R. Kearns, The University of Michigan Press, Ann Arbor 1999, s. 49, 84 . 
znaczenia cierpienia związanego ze społeczną nierównością, obawia się jednak działania politycznego, które legitymizację odnajduje jedynie w traumie. W swoich rozważaniach Berlant nawiązuje do głośnego tekstu Wendy Brown Wounded Attachments ${ }^{15}$. Brown stosuje Nietzscheańskie pojęcie ressentiment do przeprowadzenia krytyki polityki tożsamości, która programowo podtrzymuje przy życiu bolesne doświadczenia przemocy i podporządkowania - nieustannie w nie inwestuje. Tak upolityczniona tożsamość opiera swoje istnienie na doświadczeniu wykluczenia, które zwalcza je i równocześnie czyni z niego podstawę swojej egzystencji. Doznana krzywda staje się - zgodnie z zasadą resentymentu - podstawą moralnej przewagi, dlatego zyskuje kluczowe znaczenia dla ukonstytuowania się podmiotu i związania go już na zawsze z niemożliwą do przepracowania traumą. Wendy Brown nazywa to zjawisko etycyzacją polityki, ale tego rodzaju etyczność zdaniem Brown opiera się na odwróconych wartościach, jakie wytwarza resentyment. Lauren Berlant, rozwijając jej tezy, zwraca uwagę na to, że właśnie w obrębie świadectw Zagłady przeszłość została ustanowiona jako coś niemożliwego do przepracowania i porzucenia.

W takim kontekście można też odczytać niektóre wątki głośnego sporu między Nancy Fraser i Axelem Honnethem ${ }^{16}$. Fraser poszukuje normatywnych uzasadnień dla żądania sprawiedliwości społecznej, nieufnie odnosi się do zbytniego akcentowania kwestii psychologicznych i etycznych. Normatywną podstawą sprawiedliwości społecznej powinna być możliwość jak najswobodniejszego uczestnictwa w interakcjach społecznych. Aktywność działania, sprawczość, a nie reaktywność resentymentu staje się tutaj podstawą uprawiania polityki tożsamości. Honneth, odpowiadając Fraser, dostrzega jednak słaby punkt jej rozumowania, zarzucając jej, że tego rodzaju normatywizacji podlegają tylko te żądania sprawiedliwości, które zyskały już uznanie społeczne, są dostatecznie widzialne i znalazły wyraz w programach politycznych. Axel nazywa je „nowymi ruchami społecznymi”, umieszczając w ich kręgu feminizm, ruchy LGBT, walkę z rasizmem. Atakuje Fraser za dostarczanie w ten sposób ruchom politycznym o podłożu tożsamościowym znormatywizowanych uzasadnień żądania redystrybucji dóbr materialnych. Gdyby przyjąć takie założenie, dowodzi Honneth, walka

15

W. Brown Wounded Attachments, „Political Theory” August 1993 Vol. 21, No. 3.

N. Fraser, A. Honneth Redystrybucja czy uznanie? Debata polityczno-filozoficzna, przeł. M. Bobako, T. Dominiak, Wydawnictwo Naukowe Dolnośląskiej Szkoły Wyższej Edukacji TWP we Wrocławiu, Wrocław 2005. 
z niesprawiedliwością ekonomiczną kapitalizmu toczyłaby się wyłącznie w ramach istniejących ruchów emancypacyjnych. Dyskryminacja o charakterze tożsamościowym byłaby tutaj podstawą do zgłaszania roszczeń ekonomicznych. Honneth natomiast uważa, że olbrzymie obszary biedy materialnej wciąż znajdują się poza ramami widzialności społecznej i ustabilizowanych ideologicznie ruchów emancypacyjnych:

Każda krytyczna teoria społeczna zamykająca się jedynie w ramach celów normatywnych, które zostały już publicznie wyartykułowane w ruchach społecznych, nierozważnie bierze na siebie ryzyko afirmacji polityczno-moralnego poziomu konfliktu, który panuje w danym społeczeństwie: $\mathrm{z}$ istotnego moralnie doświadczenia cierpienia potwierdzone zostaje tylko to, co przekroczyło już próg massmedialnej widzialności, bez szansy na to, byśmy - niejako z pozycji adwokata - mogli stematyzować i napiętnować takie fakty niesprawiedliwości społecznej, które dotychczas były niedostępne uwadze publicznej. [...] Zbyt łatwo abstrahuje się przy tym od tych doświadczeń cierpienia i niesprawiedliwości społecznej, które w wyniku filtrującego oddziaływania mieszczańskiej sfery życia publicznego nie osiągnęły jeszcze poziomu politycznej artykulacji i zorganizowania. ${ }^{\mathbf{1 7}}$

Honneth twierdzi zatem, że podstawą walki o sprawiedliwość społeczną powinny wciąż być świadectwa cierpienia; zauważa też konieczność poszerzenia sfery publicznej. Za wzór stawia monumentalny tom La misère du monde przygotowany pod kierownictwem Pierre'a Bourdieu ${ }^{\mathbf{1 8}}$. Tworzy go złożony splot świadectw i komentarzy opisujących współczesne doświadczenia biedy w społeczeństwach rozwiniętego kapitalizmu. Odpowiadając Honnethowi, Fraser atakuje go za skłonność do psychologizowania i moralizowania, zjawisko to nazywa „psychologią moralną" i uważa ją za niewłaściwą, a wręcz szkodliwą podstawę formułowania celów politycznych. Podważa możliwość budowania jakiejkolwiek politycznie skutecznej teorii krytycznej na podstawie doświadczenia „przedpolitycznego cierpienia”19. Nie zgadza się na to,

17 Tamże, s. 115.

La misère du monde, sous la direction de P. Bourdieu, Éditions du Seuil, Paris 1993.

19 N. Fraser, A. Honneth Redystrybucja czy uznanie? Debata polityczno-filozoficzna, przeł. M. Bobako, T. Dominiak, Wydawnictwo Naukowe Dolnośląskiej Szkoły Wyższej Edukacji TWP we Wrocławiu, Wrocław 2005, s. 185. 
żeby „moralno-psychologiczne kwestie subiektywnej motywacji uzyskiwały priorytet względem kwestii wyjaśnienia społecznego i normatywnego"20.

Zarysowany tutaj pobieżnie wątek pokazuje, że najciekawsza dziś debata na temat świadectwa być może toczy się właśnie w obszarze „nowych ruchów społecznych", polityki tożsamości i medialnych cyrkulacji świadectw poszerzających rozumienie sfery publicznej. Sama koncepcja świadectwa jest jednak ideologicznie obciążona za sprawą przynależności do archiwum traumy, dlatego często paraliżuje możliwość prowadzenia debaty publicznej (taki zarzut stawia właśnie Fraser „psychologii moralnej” Axela Honnetha). Dzisiejsza refleksja nad świadectwem powinna rozważyć jego znaczenie dla konstytuowania się dwóch potężnych ideologemów: traumy i resentymentu, pokrewnych i wykluczających się zarazem. Rozróżnienie to powinno dokonać się właśnie w obszarze napięć ideologicznych, a nie w sferze doświadczenia. W obszarze doświadczenia bowiem trauma i resentyment są często tym samym, a dopiero odczytywane jako ideologemy zyskują swoją odrębność. Najlepszym na to przykładem są rozważania Jeana Amery'ego, ocalałego z Zagłady Żyda, o resentymencie. Uznanie resentymentu, a nie ukrywanie go pod zasłoną traumy, pozwala mu sformułować wobec sprawców popełnionych w przeszłości zbrodni jasne i uzasadnione żądanie przywrócenia sprawiedliwości, a przynajmniej przyznania się do tego, że zasada sprawiedliwości została brutalnie przez nich pogwałcona.

Świadectwo zakłada możliwość zdeponowania go w archiwum, a tym samym legitymizuje władzę takiego archiwum nad sferą polityczną. Radykalne formy działania politycznego w obrębie „nowych ruchów społecznych", by pozostać już przy sformułowaniu Honnetha, chętniej jednak posługują się kategorią performansu, który często - a wręcz z zasady - opiera się na strukturze świadectwa. Performans jest skrajnie podmiotowy, jest świadectwem w działaniu, ujawnia napięcia w polu politycznym, rejestruje akty dyskryminacji, nie daje jednak publiczności władzy nad nim.

Peggy Phellan w swojej wybitnej książce poświęconej politycznym aspektom performansu ${ }^{21}$ odwróciła lewicową retorykę, która z zasady widzialności czyni podstawowe narzędzie zdobywania władzy. Phellan pokazuje, że tylko złożony splot widzialnego i niewidzialnego, oznakowanego i nieoznakowanego decyduje o miejscu w hierarchii władzy. Często niewidzialność właśnie zapewnia największą władzę. Absolutyzowanie racji etycznych prowadzi

Tamże, s. 187.

P. Phelan Umarked: the Politics of Performance, Routledge, London 1993. 
natomiast do ukrycia realnej władzy politycznej, wyłączenia jej z obszaru debaty publicznej. W radykalnej koncepcji, zaproponowanej przez Peggy Phelan, performans wymyka się zarówno polityce widzialności, jak i polityce tożsamości, a jego znaczenie nie może nigdy zostać w pełni uchwycone. Performans stawia opór archiwizacji, oddziałuje bezpośrednio, nie poddaje się testom prawdy, powraca w efemerycznych realizacjach, toczy się „tu i teraz", wytwarza ciekawe przekształcenia sfery publicznej (wystarczy wspomnieć ideę counterpublic Michaela Warnera ${ }^{22}$ czy semipublic José Estebana Muñoza ${ }^{23}$ ). Perfomanse analizowane przez Phelan ujawniają bardzo złożone pole konfliktów i napięć, na którym się zrodziły. Jej interpretacja sławnego filmu Jennie Livingstone Paris Is Burning, przedstawiającego środowisko czarnoskórych i latynoskich gejów z Harlemu i Bronksu, ujawnia próbę zawłaszczenia subwersywnego performansu przez konwencje filmu etnograficznego, zastosowane przez Livingstone, a w konsekwencji tego rodzaju zabiegów - zamianę performansu w filmowe świadectwo. Dla Phelan polityczne znaczenie filmu powstaje dokładnie w tych miejscach, w których twórczyni filmu Paris Is Burning ponosi porażkę.

Performans jest złączony ze świadectwem jak dwie strony wstęgi Möbiusa, wypracował jednak skuteczniejsze strategie opierania się cenzurze i ideologicznym naciskom. Jest bardziej aktywny niż reaktywny, manifestuje raczej wolność swojego aktualnego zaistnienia niż traumatyczny ciężar przeszłości, nawet jeśli bez niego nie mógłby zaistnieć. Wbrew próbom podporządkowania performansu władzy archiwum, jakie dostrzegam w teoretycznych koncepcjach Philipa Auslandera i Rebekki Schneider polemizujących z koncepcją Peggy Phelan ${ }^{24}$, ale niepodejmujących zasadniczego politycznego wątku jej rozważań - wciąż potrafi przemieszczać się poza jego granice.

M. Warner Publics and Counterpublics, Zone Books, New York 2002. ment, Routledge, London 2011), jak i Philip Auslander (Liveness: Performance in Mediatized Culture, Routledge, London 1999) polemizują z Peggy Phelan głównie w związku z jej tezą o efemeryczności performansu, nie odnosząc się jednak do całościowej koncepcji polityczności performansu przedstawionej w Unmarked. Phellan bynajmniej nie ukrywa możliwości rejestrowania performansów, zwraca jednak uwagę na istotne przesunięcia, jakie dokonują się w sferze ich politycznej skuteczności. 


\section{Abstract}

\section{Grzegorz Niziołek}

JAGIELLONIAN UNIVERSITY (CRACOW)

The Power of Testimony: Between Politics and Ethics

Niziołek analyses the ethical and political aspects of the situation of giving testimony. He explores how research on the Holocaust helped establish current discourses on testimony within various emancipatory movements and why these two fields seem incompatible. Niziołek's key concept is the political performativity of trauma, which allows testimony to be used to transform power relations and the concept of the public sphere.

\section{Keywords}

trauma, Holocaust, emancipation movements, public sphere, testimony, performance 